Archaeological Journal

\title{
The Fernyhalgh Chalice and Paten
}

\section{By T. M. Fallow M.A.}

To cite this article: By T. M. Fallow M.A. (1885) The Fernyhalgh Chalice and Paten, Archaeological Journal, 42:1, 420-423, DOI: 10.1080/00665983.1885.10852183

To link to this article: http://dx.doi.org/10.1080/00665983.1885.10852183

曲 Published online: 15 Jul 2014.

Submit your article to this journal $\widetilde{ }$

III Article views: 2

Q View related articles $₫$ 


\section{THE FERNYHALGH CHALICE AND PATEN.}

\section{By T. M. FALLOW, M.A.}

There is preserved at the Roman Catholic church at Fernyhalgh, in Lancashire, the very curious silver-gilt chalice with its paten, of which illustrations are given from photographs by Mr. Beattie of Preston.

- The bowl of the chalice is somewhat conical in form. The stem and knot are hexagonal. The knot is almost exactly in the centre of the stem, and its six facets are filled with a four-leaved ornament in blue enamel; the upper side only has open tracery. The chief peculiarity, however, is the base, which, unlike that of any other known chalice, is octagonal, instead of being either circular or hexagonal. This is the more noteworthy when the hexagonal form of the stem and knot is taken into account. On the front compartment, in a small square, are

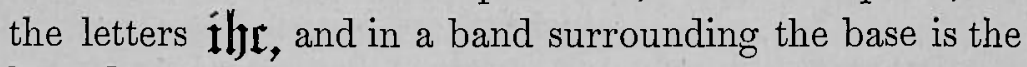
legend:-

\section{Dosnz $\mid$ maguir $|\mathfrak{r e x} \quad \mathfrak{f}| \mathfrak{l m a}$ $\mathfrak{L C r r r}|\mathfrak{x} \dot{x} \mathfrak{x}|$}

The dimensions are:- Height $5 \frac{3}{1}$ in. ; diameter of the bowl $3 \mathrm{in}$.; depth of the bowl $1 \frac{3}{4}$ in.; diameter of the base from point to point 5 in., and from hollow to hollow 4 in. The chalice is entirely gilt, and in constant use; it has no hall-marks.

The paten has a narrow rim, and a plain circular depression. In the centre is a circle containing an unusual treatment of the Manus Dei, the Divine Hand being gloved, and on either side of it are the sun and moon. The paten is parcel-gilt, and $3 \frac{3}{4}$ in. in diameter ; it is not in use, and has no hall marks.

How this chalice and paten came to Lancashire, and 
into the possession of the Roman Catholics of Fernyhalgh is not known, nor is there any direct evidence as to their former history, or the church to which they belonged. There seems, however, some ground for the presumption that they may have been a gift by the Maguire, whose name the chalice bears, to the Franciscans of Donegal. Conosus or Cuconnaught Maguire became prince of Fermanagh in 1527, and was ten years later treacherously murdered by some of his rival kinsmen. He was on very friendly terms with the Donegal Franciscans, and the history of Donegal, well-known as the Annals of the Four Masters, was, it will be remembered, compiled by members of the Franciscan order in Donegal. It thus refers to him :- " 1537. Maguire (Cuconnaught, the son of Cuconnaught, son of Brian, son of Philip) Lord of Fermanagh, a charitable and humane man, the most renowned for dexterity of hand, nobleness, and hospitality, that came of the race of the Collas for a long period of time; who had brought under his jurisdiction [that tract of country] from Clones to Cael-Uisge; the suppressor of thieves and evil doers; a man who possessed happiness and affluence in his time, was, on the 8th of October, treacherously slain on Creachan, an island on Lough Erne, belonging to the Friars, by the descendants of Thomas Maguire, and the descendants of Turlough, i.e. by Flaherty, the son of Philip, son of Turlough Maguire. He was first buried in Devenish, but was sometime after disinterred by the Friars Minor, who carried him to the monastery of Donegal, and there interred him in a becoming manner."

In 1601 the Franciscan convent of Donegal was occupied by a garrison of English soldiers, and the friars fled into the fastnesses of the country, carrying with them their chalices and vestments.

I am indebted to the Rev. James O'Laverty, of Holywood co. Down, for the following extract relating to this. It is contained in a MS. history of the Irish Franciscans compiled in 1617 at Louvain, by Father Anthony Purcell. ${ }^{2}$

1 Annals of the Kingdom of Irelund, by the Four Masters; edited by John O'Donovan, 2nd ed., Dublin, 1856, vol. v. p. 1441.
2 No. 3195 Manuscrit, Bibliotheque de Burgogne, Bruxelles. Father O'Laverty's extract is from a copy of this MS. in the possession of the Franciscans of Drogheda. 
"Anno 1600 eramus ibi, scilicet conventu Dunangallensi 40 fratres de familia, et officia divina nocturna et diurna fiebant cum cantu et solemnitatibus magnis. Habebam ipse curam sacristiæ in qua habui 40 indumenta sacerdotalia cum suis omnibus pertinentiis et multa erant ex tela aurea et argentea aliquot intertexta et elaborata auro; reliqua omnia serica. Erant etiam 16 calices argentei, et magni, ex quibus duo tum erant qui non erant deaurati ; erant et duo ciboria pro $\mathrm{s}^{\mathrm{mo}}$ sacramento. Suppellex satis honesta; ecclesia ne vitro quidam caruit. Sed ingraviscente bello, et hereticis aliqualiter prævalentibus, tandem potuerant id efficere, ut principe O'Donnelo in aliis negotiis occupato, ipsi ad oppidum Dunangall pervenerint cum exercitu, et anno 1601 in festo $\mathrm{S}$. Laurentii martyris, in monasterio præsidium militum collocarunt. Fratres, quidem, præmoniti fugerunt ad loca silvestria inde aliquot miliaribus distantia, et suppellextilem monasterii, navi impositam, ad alium tutiorem locum transtulerunt; ego ipse eram ex ultimis qui e conventu egressus sum. * * * * * Princeps O'Donnell in Hispaniam se contulit, annoque sequenti 1602 omnia loca sui dominii in hæreticorum potestatem devenerunt, et inter cætera quæ ibi perierunt, suppellex illa ecclesiastica conventus de Dunangall fuit prædæ Olivero Lamberto, gubernatori Conacix ex parte hæreticorum, qui calices in cyphos profanos convertit, et vestes sacras in diversos profanos usus convertendos scindi et delacerari curavit; et sic tum ipse conventus, tum omnis suppellex ejus periit."

General Lambert, into whose hands the spoil of the Donegal convent fell, was connected with Lancashire, and had married into the old Lancashire family of Fleetwood. It seems not unreasonable to believe, therefore, that if the Fernyhalgh chalice with the inscription it bears was among the spoil of the Donegal Franciscans which came into his possession, it would be specially preserved as a trophy, and so taken back by him into England.

Hence, I think, we may venture to agree with Father O'Laverty, who suggests that, although there is no proof of it, yet there is fair ground for the double presumption; first, that the chalice was given by Cuconnaught Maguire to the Donegal Franciscans, and was one of the sixteen 


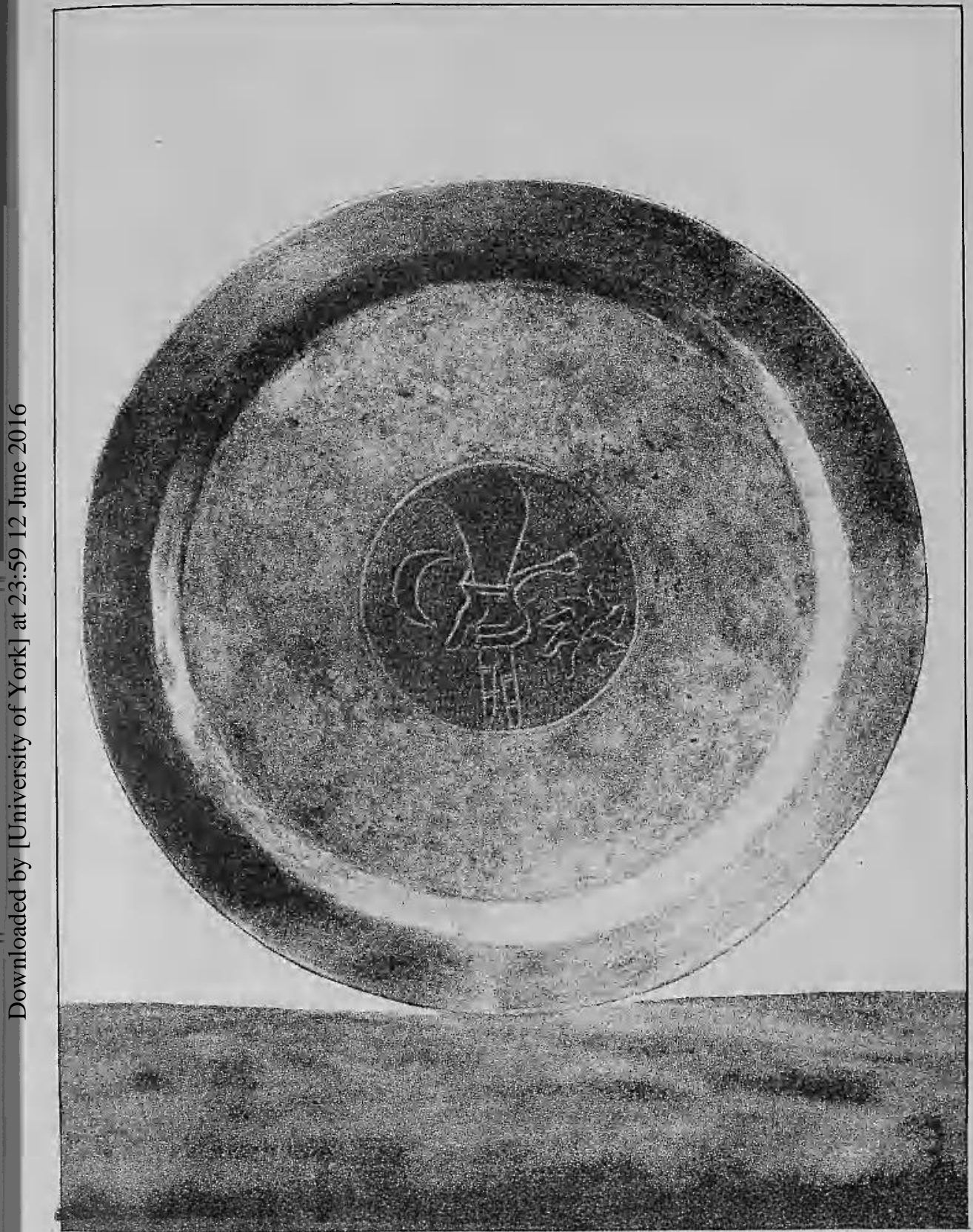

I HK-l'HOTO, SPMAGUE A C' LONDON.

The Fernyhalgh PATEN. (Slightly enlarged.) 
chalices which fell into General Lambert's hands. Secondly, that Lambert's connection with Lancashire accounts for the presence of the chalice at the present day in that county.

These vessels are of unusual interest; and I have to thank the Rev. W. Gordon, the priest of the church at Fernyhalgh, for the opportunity afforded me of examining them. 